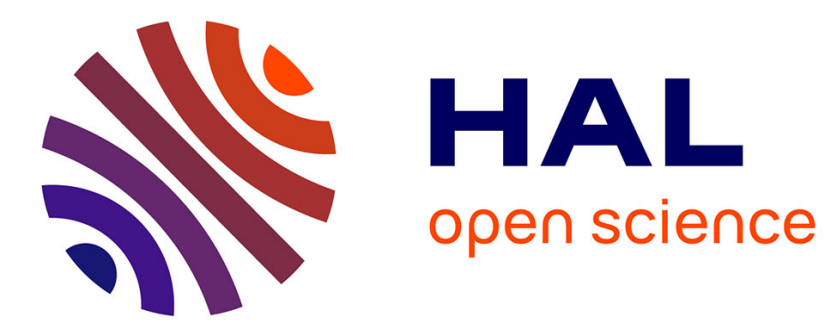

\title{
Climate-growth variability in Quercus ilex L. west Iberian open woodlands of different stand density
}

Guillermo Gea-Izquierdo, Dario Martín-Benito, Paolo Cherubini, Cañellas

Isabel

\section{- To cite this version:}

Guillermo Gea-Izquierdo, Dario Martín-Benito, Paolo Cherubini, Cañellas Isabel. Climate-growth variability in Quercus ilex L. west Iberian open woodlands of different stand density. Annals of Forest Science, 2009, 66 (8), 10.1051/forest/2009080 . hal-00883563

\section{HAL Id: hal-00883563 https://hal.science/hal-00883563}

Submitted on 1 Jan 2009

HAL is a multi-disciplinary open access archive for the deposit and dissemination of scientific research documents, whether they are published or not. The documents may come from teaching and research institutions in France or abroad, or from public or private research centers.
L'archive ouverte pluridisciplinaire HAL, est destinée au dépôt et à la diffusion de documents scientifiques de niveau recherche, publiés ou non, émanant des établissements d'enseignement et de recherche français ou étrangers, des laboratoires publics ou privés. 


\title{
Climate-growth variability in Quercus ilex L. west Iberian open woodlands of different stand density
}

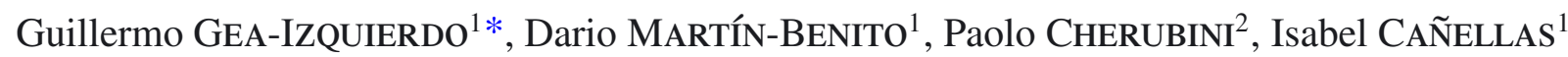 \\ ${ }^{1}$ Departamento Sistemas y Recursos Forestales. CIFOR-INIA, Crta. La Coruña km 7.5, 28040 Madrid, Spain \\ ${ }^{2}$ Swiss Federal Research Institute WSL, 8903 Birmensdorf, Switzerland
}

Keywords:

holm oak /

dendroecology /

climate change /

warming /

dehesas /

tree rings

(Received 16 March 2009; accepted 27 May 2009)

\author{
Mots-clés : \\ chêne vert / \\ dendroécologie / \\ changement climatique / \\ réchauffement / \\ dehesas / \\ cernes des arbres
}

\begin{abstract}
- We present the longest tree-ring chronology (141 y) of Quercus ilex L. (holm oak), and discuss the species climate-growth relationships and the influence of stand density on tree sensitivity to climate. - Similarly to Quercus suber L., the most influential climatic variables upon holm oak growth were late spring and early summer precipitation, which enhanced growth, and high temperatures in the previous August and current July, which negatively affected growth.

- High density stands responded to similar climatic factors as low density stands, but their response was generally weaker. Holm oak sensitivity to climate has increased in recent decades, which might be related to increasing temperatures in the region. Sensitivity was higher in low density stands. Additionally, the effect of summer stress on growth seems to have increased during the same period, similarly to other species in the Iberian Peninsula, suggesting that trees are more vulnerable to climatic changes.

- Stand density could buffer the response to climate by smoothing climatic extremes. Nevertheless, the effect of competition might reverse this positive effect at the individual tree level. Precautions should be taken before providing management guidelines regarding the effect of climate change and stand density on holm oak.
\end{abstract}

\footnotetext{
Résumé - Variabilité des relations climat- croissance chez Quercus ilex L. dans des peuplements forestiers ouverts de différentes densités dans l'ouest de la péninsule Ibérique.

- Nous présentons la plus longue chronologie de cernes (141 ans) de Quercus ilex L. (chêne vert) comme et nous discutons les relations climat-croissance chez cette espèce et l'influence de la densité du peuplement sur la sensibilité des arbres au climat.

- De façon similaire à Quercus suber L., les variables climatiques les plus influentes sur la croissance du chêne vert ont été les précipitations de la fin du printemps et du début de l'été, qui ont augmenté la croissance, et les températures élevées d'août de l'année précédente et du mois de juillet de l'année, qui ont affecté négativement la croissance.

- Les peuplements de densité élevé ont répondu à des facteurs climatiques similaires que les peuplements de faible densité mais leur réponse a été généralement plus faible. La sensibilité du chêne vert au climat a augmentée au cours des dernières décennies, elle pourrait être liée à l'augmentation des températures dans la région. Cette sensibilité est plus élevée dans les peuplements de faible densité. En outre, le effet du stress estival sur la croissance semble avoir augmenté au cours de la même période, de la même façon que pour d'autres espèces dans la péninsule Ibérique, ce qui suggère que les arbres sont plus vulnérables aux changements climatiques.

- La densité du peuplement pourrait amortir la réponse au climat en lissant les extrêmes climatiques. Néanmoins, les effets de la concurrence pourraient inverser cet effet positif au niveau des arbres individuels. Des précautions doivent être prises avant de fournir, pour le chêne vert, des lignes directrices de gestion concernant les effets du changement climatique et de la densité.
}

\footnotetext{
*Corresponding author: guigeiz@gmail.com; guillermo.gea@wsl.ch
} 


\section{INTRODUCTION}

The difficulties encountered in tree growth studies under climates where winter cambial dormancy is not complete (such as the tropics and subtropics) or where there is probably a second cambial stop in summer ("double-stress") as a consequence of drought (such as Mediterranean ecosystems) are well known (e.g. Cherubini et al., 2003; Fritts, 1976). Growth of trees in locations differing in altitude is likely to be influenced by different ecological limiting factors. In Mediterranean ecosystems, precipitation is the most limiting factor at low and mid-elevation sites; and the climatic signal in tree rings is likely to differ from that at high elevation sites (more temperature-limited). Thus, understanding how species from different elevation stands respond to climate is essential to infer future ecological behaviours and shifts in species distributions, and especially in drought-limited ecosystems with a future scenario of rising temperatures and decreasing precipitations (IPCC, 2007; Sumner et al., 2003).

In Mediterranean ecosystems of Western Iberia, dendroecological studies on broadleaf trees are much less abundant than those in conifer ecosystems, particularly at high elevations (Génova et al., 1993; Richter et al., 1991). Lower elevation forests in this region, such as evergreen Quercus woodlands, are likely to withstand higher water stress; thus the climatic forcing is likely to differ from that of forests growing at higher elevations. Quercus sp. (oaks) is a widespread genus in the Northern Hemisphere, and is the most important broadleaf genus in the Mediterranean region. Unlike the Mediterranean evergreen oaks, deciduous oaks have been widely used in dendrochronology (e.g. Rozas, 2005; Tessier et al., 1994). The most widespread evergreen oak species in the West Mediterranean is holm oak (Quercus ilex $\mathrm{L}$ ). Its distribution ranges in latitude from Southern France to the Anti-Atlas in Morocco, and from the sea level to over $2500 \mathrm{~m}$ a.s.l. in the Atlas Mountains (Barbero et al., 1992; Rodá et al., 1999). This wide distribution confers upon the species great potential for dendroecology if tree rings can be correctly dated despite the presence of double and absent rings (e.g. Campelo et al., 2007; Nabais et al., 1998-1999; Zhang and Romane, 1991) or lack of clear ring boundaries. The few studies carried out on this species have focused on the more mesic subspecies $Q$. ilex ssp. ilex in the Northern Mediterranean (e.g. Cherubini et al., 2003; Zhang and Romane, 1991). The other less-studied subspecies, Q. ilex ssp. ballota, is distributed in Western Iberia and North Africa (Rodá et al., 1999). The species is considered to live several hundred years (Ruiz de la Torre, 1979). Nevertheless, the longest $Q$. ilex chronology in the literature is $65 \mathrm{y}$ long (Cherubini et al., 2003).

Silviculture can play a basic role in influencing the response of tree species to limiting factors, and the effect of different silvicultural scenarios and stand densities on tree growth response to climate is likely to be a key factor for forest preservation, particularly in the driest sites. The influence of tree density on the response of trees to climate and drought is not a straightforward issue, since different approaches (e.g. ecophysiological, dendroecological, growth modelling) might give different insights (Cescatti and Piutti, 1998; Misson et al., 2003; Moreno and Cubera, 2008). Competition increases with stand density, which also buffers climate as compared to freegrowing trees, with precipitation, wind velocity, transpiration, vapour pressure and incident heat reaching the soil differing in stands of different densities (Kimmins, 1997). Many studies have demonstrated how climate-growth relationships can change over the life of a tree (e.g. Briffa et al., 1998; Carrer and Urbinati, 2006; D'Arrigo et al., 2008). In addition, recently an increase has been reported in the common variance shared among tree-ring chronologies of different species from high elevations in the Iberian Peninsula as a consequence of climate warming (Andreu et al., 2007), and an increase in aridity in the East Mediterranean, with trees responding by taking up water from deeper soil layers (Sarris et al., 2007).

Understanding past tree climate-growth relationships and their interactions with stand density are essential for future preservation of ecosystems and sustainable management. The objectives of our study were: (i) to analyse the possibility of using tree-like holm oaks (from the more xeric subspecies, Q. ilex ssp. ballota) from west Iberian open woodlands for dendroecological studies; (ii) to determine the relationship between tree-ring growth and climate in these open woodlands, comparing two different scenarios of stand densities; and (iii) to assess whether climate warming has modified the climate-growth relationship or increased the species sensitivity to climate in the two mentioned density scenarios.

\section{MATERIALS AND METHODS}

\subsection{Study site}

The study site $\left(40^{\circ} 37^{\prime} \mathrm{N}, 6^{\circ} 40^{\prime} \mathrm{W}, 700 \mathrm{~m}\right.$ a.s.1.) is located near the northwest slope of the Central Mountain Range in Spain (Fig. 1). The ecosystem consists of the typical dominant landscape in low and midelevations in the west Iberian Peninsula. The landscape is an agroforestry system (so-called "dehesa") consisting of open woodlands of evergreen tree-like oak species, particularly $Q$. ilex and $Q$. suber L., which are most probably the result of intense human management (a combination of thinning, coppicing and seeding) on original closed mixed forests (Olea and San Miguel, 2006). This might further complicate dendroecological studies and their interpretation. Tree density is generally low, allowing the existence of an understory layer of herbaceous species (mostly annual grasses), shrubs or crops, which might compete with trees for resources (Olea and San Miguel, 2006). Density has not changed much during the last few decades in this human-transformed ecosystem (García del Barrio et al., 2004) and we found no signs of recent logging in any of the study areas. Climate data from the "Salamanca-Matacán" station (1945-2005) was used in the climate-growth analyses rather than data from nearer stations (Fuentes de Oñoro (FO; precipitation), Ciudad Rodrigo (CR; temperature)) as the records extend further back, and were highly correlated with records for the common period from closer stations (Pearson $\rho>0.8$; Figs. 2A, 2B). However, a better description of the climate at the sampling sites can be gained from mean precipitation in FO (1967-2005), $609 \mathrm{~mm}$, while in CR (1943-2005) the mean temperature was $13.2^{\circ} \mathrm{C}$. 


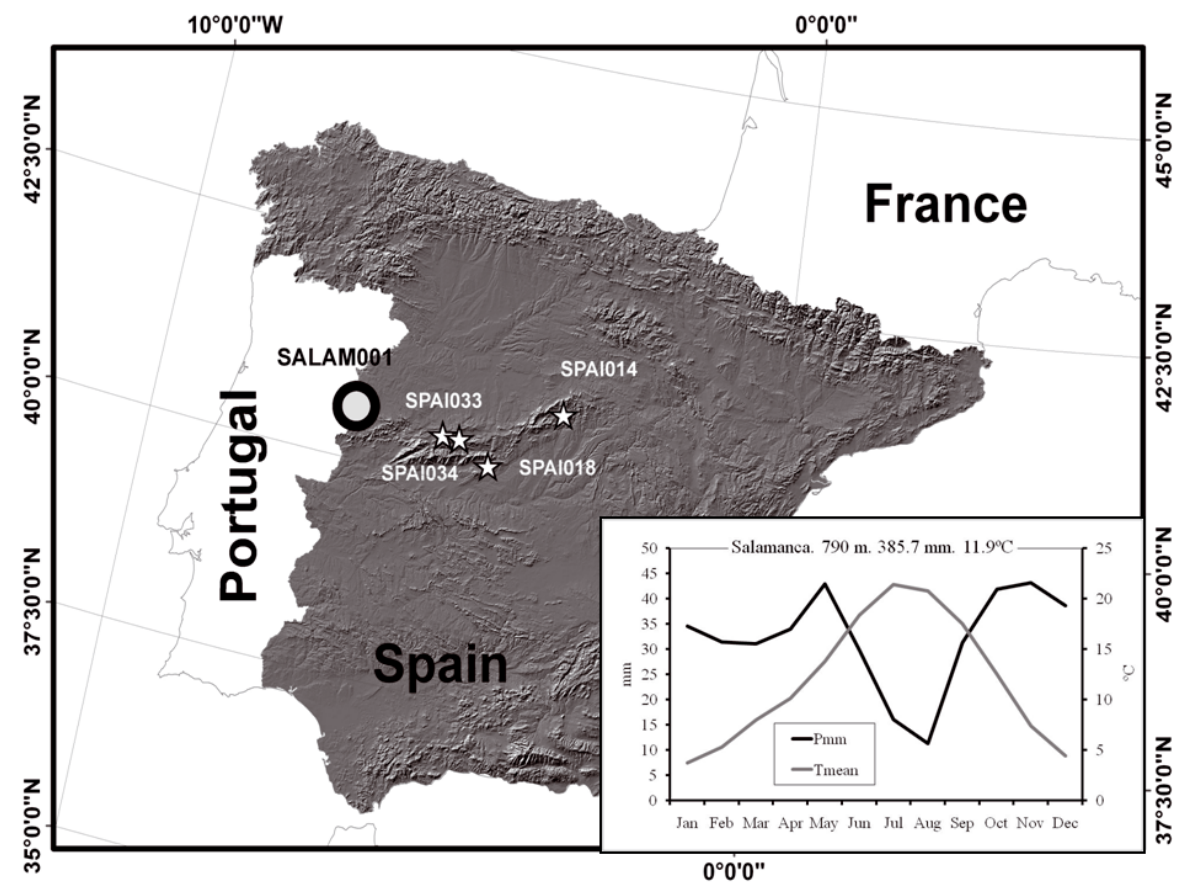

Figure 1. Geographical locations of the chronologies and Gaussen diagram of the climate data. SALAM001 = Q. ilex chronologies (SAL001, SAL002, SAL003); see Table I for nomenclature of chronologies. Pmm = precipitation $(\mathrm{mm})$; Tmean $=$ mean temperature $\left({ }^{\circ} \mathrm{C}\right)$.
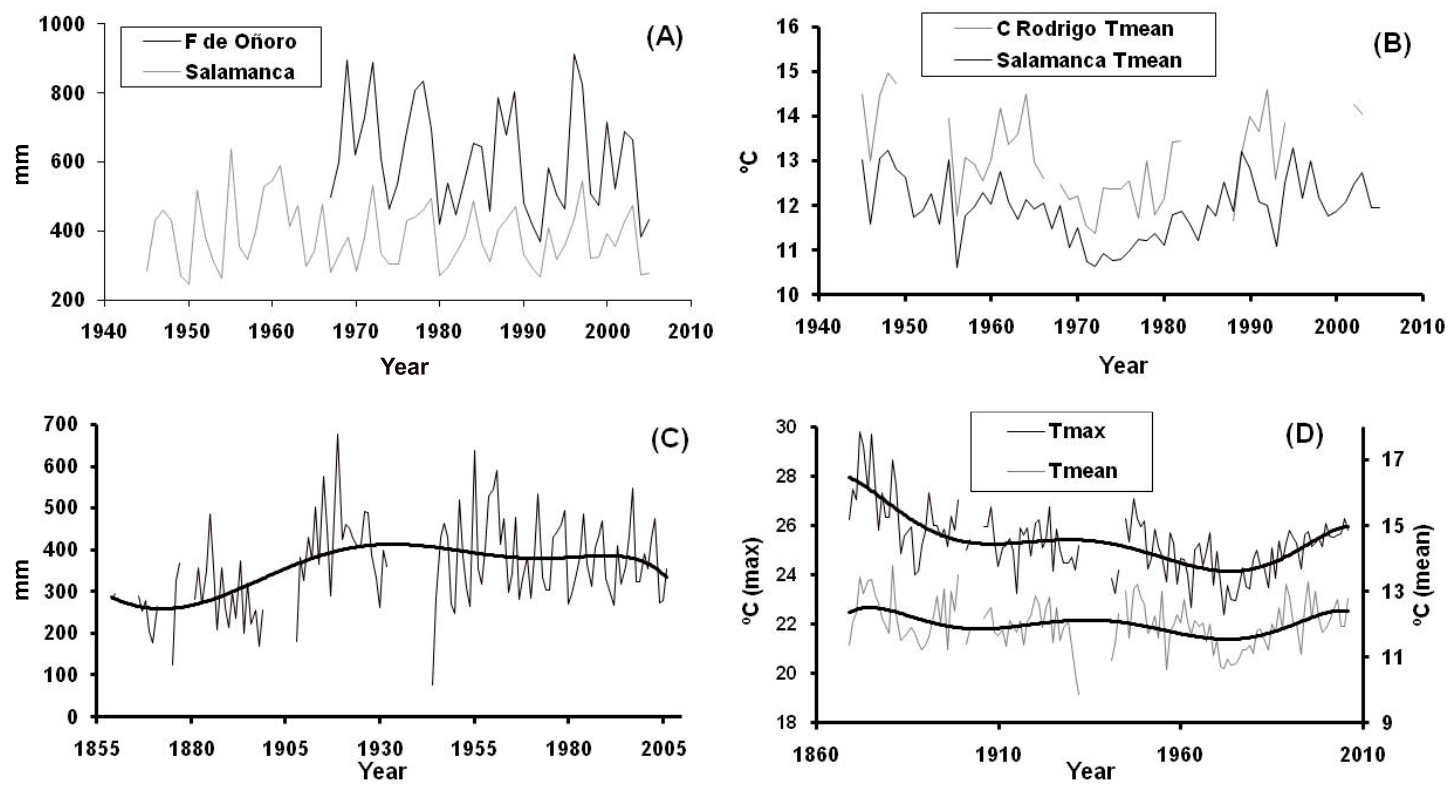

Figure 2. Climatic data from meteorological stations: (A) mean annual precipitation of "Fuentes de Oñoro" and "Salamanca"; (B) mean annual temperature of the "Ciudad Rodrigo" and "Salamanca" stations; (C) mean annual precipitation of "Salamanca"; (D) annual maximum and mean temperatures of the "Salamanca" station. 


\subsection{Sample characteristics}

Although some authors have cored young holm oaks (e.g. Cherubini et al., 2003; Zhang and Romane, 1991), with tree-like thick holm oaks it is necessary to analyse whole stem discs. Even in the exceptional case where there are very clear rings, the characteristic multiple thick parenchyma radii can interrupt the ring sequence (Cherubini et al., 2003; Fig. 3). In Spain, it is difficult to obtain samples from old trees because holm oaks are protected. Trees were logged during the construction of a highway, and cross-sections were obtained at stump height (basal sections) and at $1.30 \mathrm{~m}$. We decided to use basal sections, because all of them presented only one centre (sections at $1.30 \mathrm{~m}$ often presented multiple stems from the main branches after initial formation pruning), were generally less eccentric than sections at $1.30 \mathrm{~m}$, and the rings were proportional at different stem heights (Zhang and Romane, 1991). A total of 125 trees were sampled from 25 plots (see Gea-Izquierdo et al., 2008 for further detail on sample characteristics). Plot density ranged from 39.5 trees/ha to 210.4 trees/ha.

Cross-sections were air-dried, sanded and polished (60 to 1200 grit). Only 115 holm oaks had at least one complete radius with visible rings and without rot. First, we selected a sub-sample of trees whose growth rings were clearly distinguishable (less than 50\%) to build an initial chronology, that was finally reduced to the final 25 individuals (43 radii) used to construct the master tree-ring chronology SAL001 (Tab. I and Fig. 4). Tree rings were identified by their characteristic semi-ring-porous anatomy and ring boundaries, where darker latewood contrasts with lighter earlywood (Fig. 3). Continental sites such as the one used here tend to produce clearer rings than warmer locations (Cherubini et al., 2003). It is a common practice in dendrochronology to select only samples that clearly crossdate in order to maximise the common signal and reduce noise (Cook and Kairiukstis, 1990; Fritts, 1976), and particularly with Mediterranean species such as holm oak (Cherubini et al., 2003). Because there were no previous dendrochronological studies on this species in this ecosystem, we were particularly selective in choosing basal sections to build the chronology and establish the annual nature of tree rings (despite the intense management and climate). The estimated age of the selected samples was not significantly different from the mean age of all samples. The fact that trees from different stands were used in the chronology minimised the possible influence of pruning at stand level.

We compared our $Q$. ilex chronology with different Pinus sp. chronologies from the Iberian Central Mountain Range (Tab. II, Fig. 1 and International Tree-Ring Data Bank ITRDB: http://www. ncdc.noaa.gov/paleo/treering.html) which were used as reference chronologies to assure the existence of annual rings in SAL001. These chronologies were built with raw tree-ring width data from four locations and two species ( . sylvestris L., and P. nigra Arn), located at high altitude (1460-1630 m) forest sites in the Central Mountain Range (Tab. II; Fig. 1). The use of tree-ring chronologies of different species is common in dendrochronoloy, e.g. to compare host and non-host species of insects (e.g. Huang et al., 2008; Swetnam et al., 1985), and a good crossdate between our holm oak chronology and those of pines would add strong evidence of annual ring formation in the studied holm oaks.

Finally, we extended SAL001 to build two chronologies (SAL002 and SAL003) with trees from plots of different stand density. These two chronologies included some extra trees from those already in SAL001, classified according to the stand density where trees were growing (high, low; Table 1). SAL001 included trees from 12 plots of 108.0 trees/ha mean density; SAL002 included trees from 6 plots of density ranging from 39.5 to 80.4 trees/ha (mean 58.85 trees/ha, hence "low density chronology"); finally, SAL003 included trees from 9 plots of densities ranging from 119.8 trees/ha to 210.4 trees/ha (mean 167 trees/ha, hence "high density chronology"). SAL001 includes data from at least three crossdated radii (from two trees), whereas both SAL002 and SAL003 were limited to at least five radii, from three trees, for comparison purposes (Fig. 4).

\subsection{Analyses}

Tree-ring widths were measured using LINTAB and TSAP software (Rinntech, 2003). The raw ring width curves were first plotted and checked visually, then crossdated by the Gleichläufigkeit (Glk), $t$-value and the crossdate index (CDI), which is a combination of the Glk and $t$-values (Rinntech, 2003), and finally verified using COFECHA (Grissino-Mayer, 2001). The same procedure was used to compare the holm oak master chronology (SAL001) with those built with the 4 datasets from ITRDB. Holm oak individual series were standardised by applying a spline function with a $50 \%$ frequency response of $32 \mathrm{y}$ and the autocorrelation was removed using ARSTAN (Cook, 1985). Such a flexible spline (high-frequency smoothing) was used because our holm oak stands were managed and abrupt growth changes were expected from pruning and thinning (Briffa et al., 2002; Macías et al., 2006). Dimensionless ring width indexes (RWI) were computed for all series by dividing the observed raw ring width values by the fitted spline values. Detrended series were then averaged using a robust estimation of the mean. Residual chronologies were selected for further analyses (Cook, 1985).

To study the relationship of the holm oak chronology with climate, we used Pearson correlation coefficients and a response function using DENDROCLIM2002 (Biondi and Waikul, 2004). Climate data from 1945 to 2005 was used in the climate-growth relationship analyses because climate data before 1945 was not complete. The mean sensitivity (MS, a measurement of the relative difference from one tree ring to the next and thus the year-to-year variation) was analysed for the holm oak chronologies and for running windows of $30 \mathrm{y}$, as an indicator of the responsiveness of trees to environmental factors (Fritts, 1976; Kaennel and Schwreingruber, 1995). The stationarity and consistency of climate-growth relationships over time were further analysed using the Pearson correlation coefficients for running windows of $30 \mathrm{y}$ to check whether the growth-climatic relationship is constant over time or whether it responds to the changing climate in the last few decades, particularly warming. The critical alpha value was modified using the Bonferroni correction when calculating running correlations with annual precipitation, to account for dependence in the multiple-comparison running correlation analyses.

\section{RESULTS}

\subsection{Population climate-growth relationships}

The months of maximum and minimum precipitation in the study area are May and November, and July and August, respectively. Inter-annual variability of summer precipitation was higher than that of summer temperatures because summers can be wetter or drier but they are always hot (Fig. 2). An 


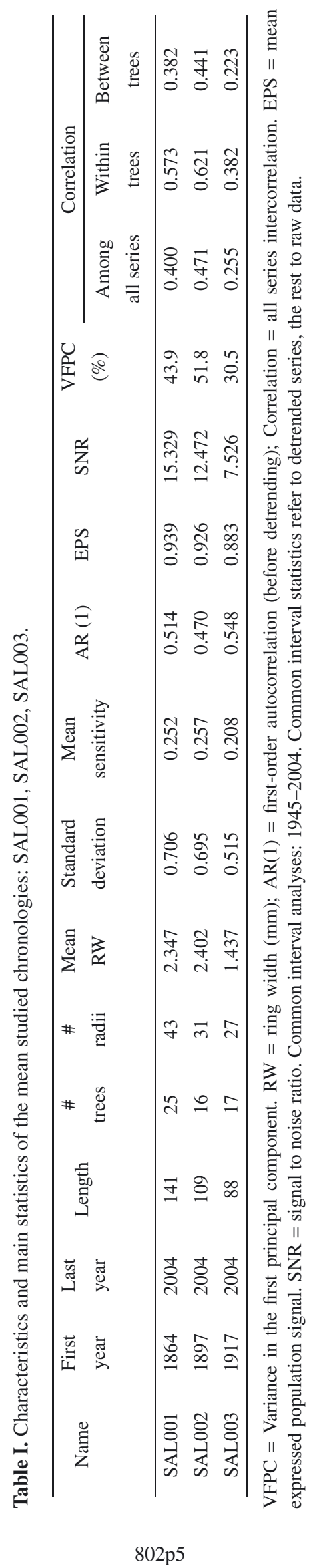




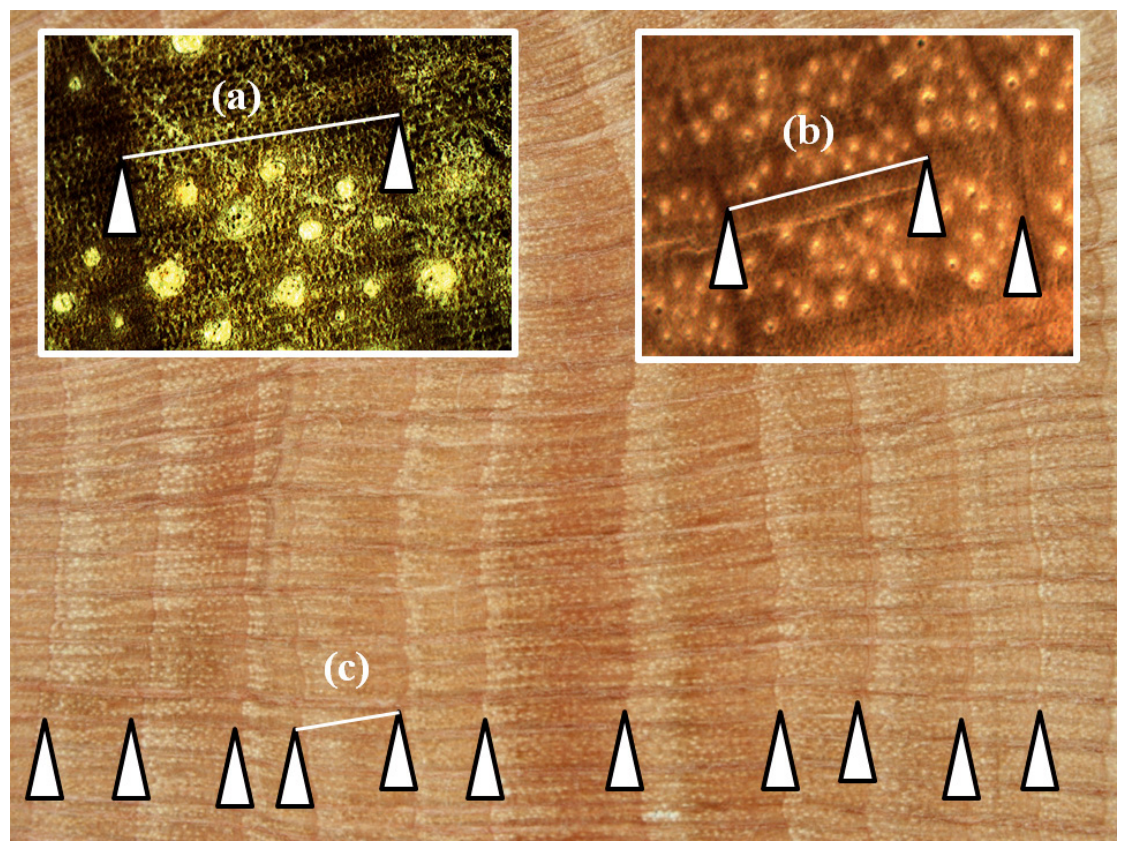

Figure 3. Details of holm oak annual rings and ring anatomy. White triangles correspond to annual ring boundaries. (a) $0.98 \mathrm{~mm}$; (b) $2.86 \mathrm{~mm}$; (c) $5.00 \mathrm{~mm}$ aprox.
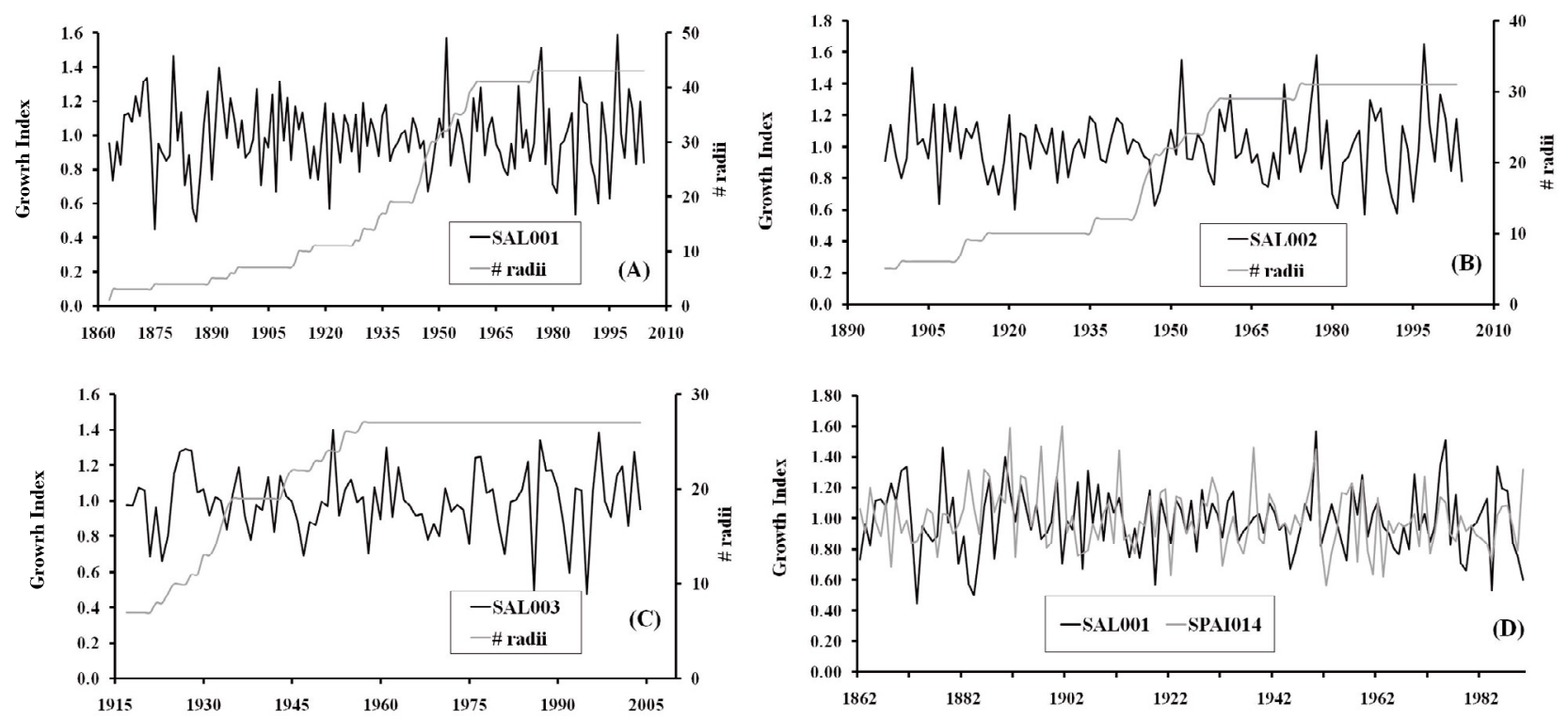

Figure 4. (A) Mean chronology and number of radii used; (B) SAL002; (C) SAL003; (D) growth indices of SAL001 and the highest correlated chronology (SPAIN014). Only the overlapping period is showed for comparison purposes.

increase in annual mean temperature and a slight decrease in precipitation have been observed in the region since the $1960 \mathrm{~s}$ (Fig. 2). Although the decrease in precipitation was not significant, a consistent decrease in precipitation has been reported over the last few decades in west Iberia (Rodrigo and Trigo, 2007). Precipitation during the second half of the 19th century was lower than in the last decades of the 20th century, whereas temperatures were higher. Summer precipitation does not seem to exhibit any trend during the last few decades (not shown).

The main statistics for the holm oak chronologies are shown in Table I. SAL001 crossdated well with several pine chronologies from the surrounding mountain areas (Tab. II and Fig. 4D) which, together with the high correlations 
Table II. Data series used and source. Pearson correlation, Glk and CDI calculated between each series with SAL001 for the corresponding overlapping period. Data are archived at the ITRDB.

\begin{tabular}{lcccccccccc}
\hline $\begin{array}{l}\text { Series } \\
\text { name }\end{array}$ & Species & Latitude & Longitude & Altitude & Pearson & Glk & CDI & $\begin{array}{l}\text { Series } \\
\text { length }\end{array}$ & Authors \\
\hline SPAI014 & & 41.01 & -3.50 & 1620 & 0.253 & $62^{* *}$ & 24 & $1791-1992$ & Yuste Herederu, I. \\
SPAI033 & Pinus sylvestris L. & 40.20 & -5.10 & 1465 & 0.302 & $62^{* *}$ & 15 & $1813-1985$ & Richter, K. \\
SPAI034 & & 40.20 & -5.08 & 1470 & 0.168 & $60^{*}$ & 11 & $1769-1985$ & Richter, K. \\
SPAI018 & Pinus nigra Arn. & 40.26 & -4.56 & 1500 & 0.386 & $61^{* *}$ & 19 & $1687-1989$ & Génova Fuster, M. \\
SAL001 & Quercus ilex L. & 40.37 & -6.40 & 700 & - & - & - & $1862-2004$ & - \\
\hline
\end{tabular}
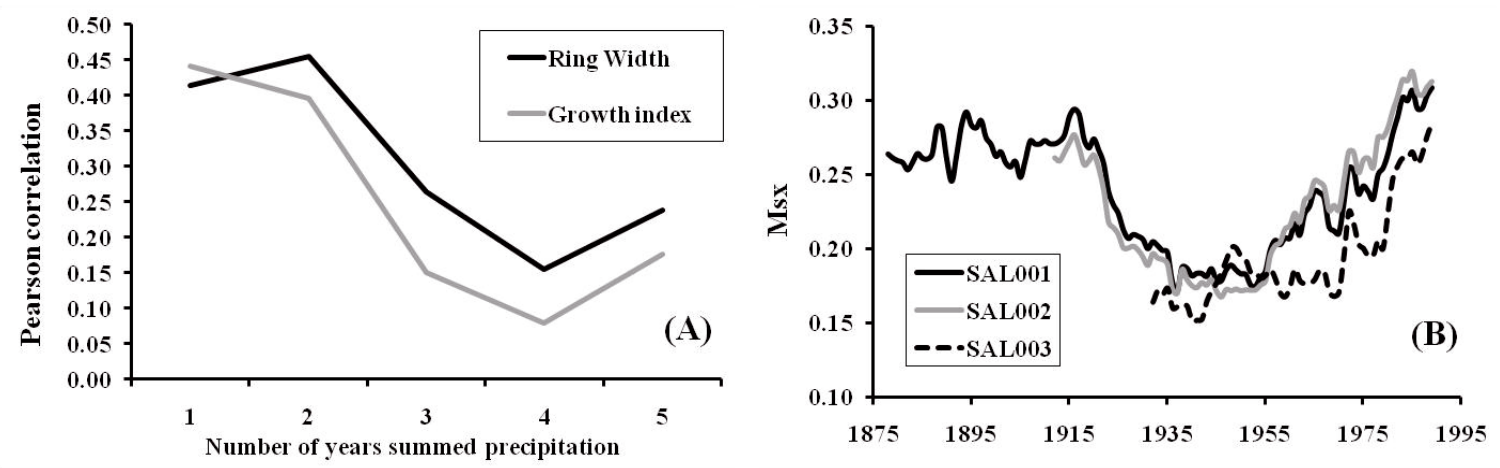

Figure 5. (A) Pearson correlation coefficients between cumulative annual precipitation (1945-2004) and ring width index (dotted line) and raw ring width (solid line) of SAL001; (B) 30-y running mean sensitivity. Msx = mean sensitivity. The $x$-axis in (B) shows the mid-year of the 30-y period.

found between growth and climate, supports the hypothesis of distinguishable annual ring formation in the species (e.g. Cherubini et al., 2003). When analysing the correlation with accumulated annual precipitation, the highest correlations of ring width were with total precipitation of the current $(\rho=0.4417 ; p=0.0004)$ and previous year $(\rho=0.3959$; $p=0.0019$, Fig. 5A). Maximum temperatures in summer and precipitation in spring and early summer were the most influential climatic factors for tree growth (Fig. 6), in accordance with the expected drought stress in the water-limited ecosystem studied. Minimum temperatures during the previous November and December were positively correlated with growth (Fig. 6D), whereas growth was reduced by high mean temperatures during the current July and previous August (Fig. 6B). Overall, climate variables in July showed the highest correlations with growth.

Climate-growth relationships varied through the life of the holm oaks (Fig. 7). The link between tree growth and annual precipitation during the annual growth period seems to have become more pronounced since the 1960s, whereas the relationship with summer precipitation has decreased (Fig. 7A). Besides this decrease in the relationship with precipitation, summer temperatures are becoming more negatively correlated with growth as they warm (Fig. 7B). Tree sensitivity to climate has increased in recent years (Fig. 5B), although this sensitivity was still lower than in the second half of the 19th century, coinciding with the local minimum precipitation and maximum temperatures previously described.

\subsection{Tree density influence on tree response to climate}

Correlation with annual mean precipitation was similar in SAL002 $(\rho=0.4391$ for $t ; \rho=0.4333$ for $[t+(t-1)])$ and $\operatorname{SAL003}(\rho=0.4356$ for $t ; \rho=0.3996$ for $[t+(t-1)])$, but there were some differences when studying the relationship with monthly climatic data (Fig. 6). The significant correlations of the two different density chronologies with specific months for mean and minimum temperatures were the same as those significant in SAL001 (Fig. 6) but generally lower in SAL003 than in SAL002 (e.g. for July mean temperature, $\rho=-0.3168$ for SAL002, whereas $\rho=-0.2413$ for SAL003). Precipitation also followed the same rule (smoother correlations in SAL003), with the exception of November, which was significantly correlated only in high density stands (Figs. 6E, 6F), except in the 90s, when the correlation in low density stands approached that in high density stands (Fig. 7A). Finally, maximum temperature significant correlations were similar in both densities except for January and March, which were greater in the high density chronology. It is noticeable that the negative relationship with January maximum temperature has diminished during the last few years in both densities (Fig. 7B).

\section{DISCUSSION}

\subsection{Population response to climate}

As has been previously demonstrated for shorter tree-ring chronologies, it is difficult but possible to use holm oaks for 

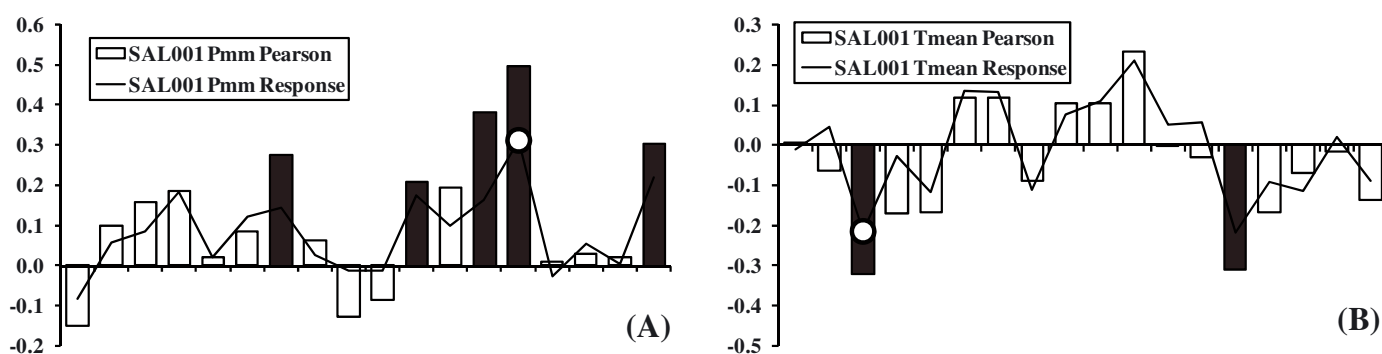

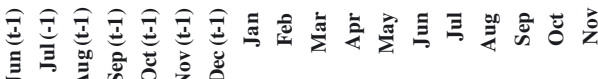
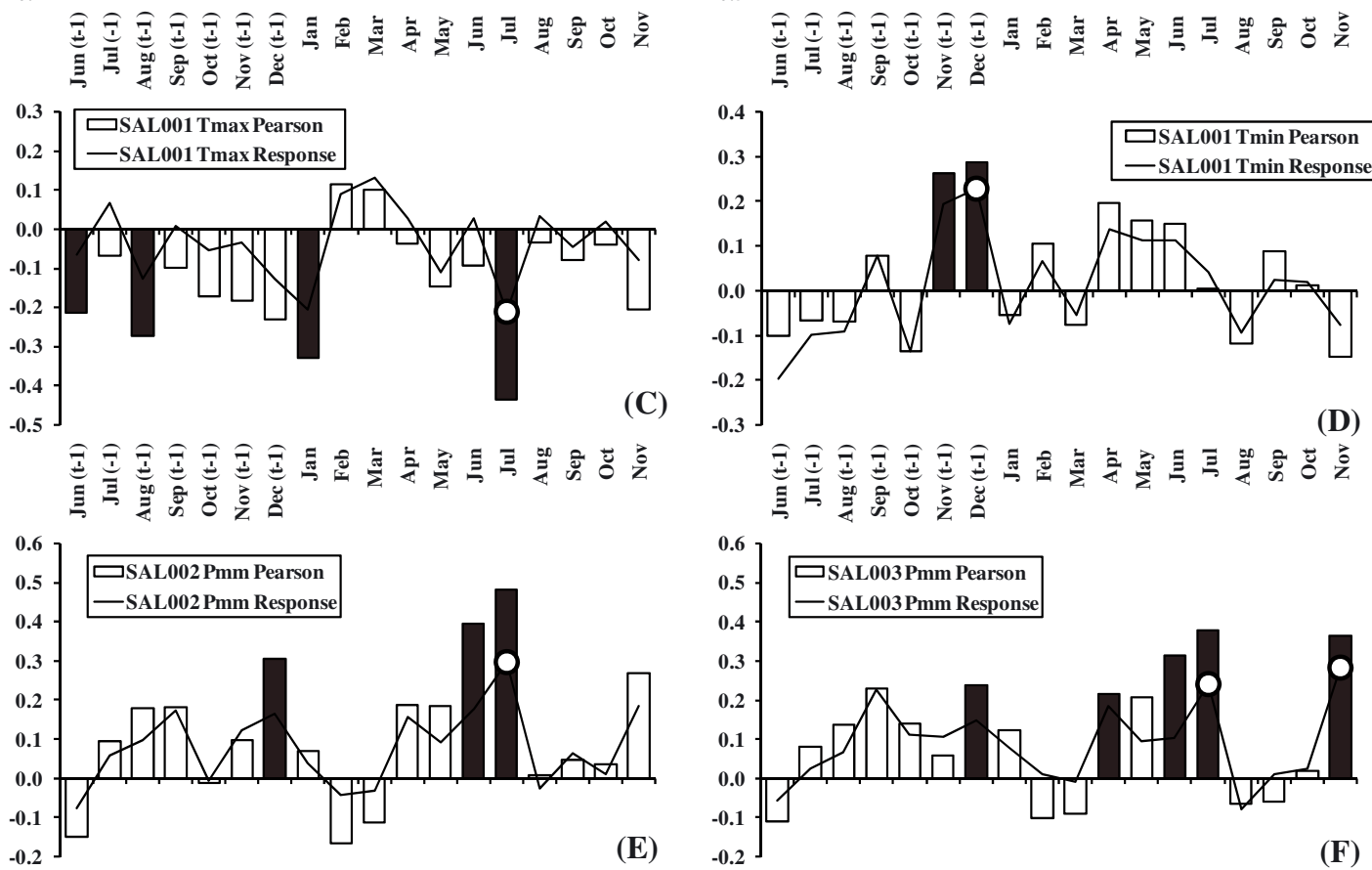

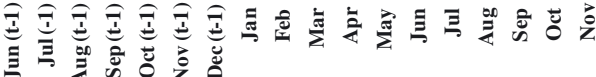

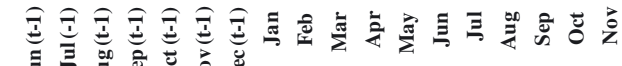

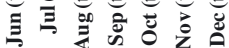
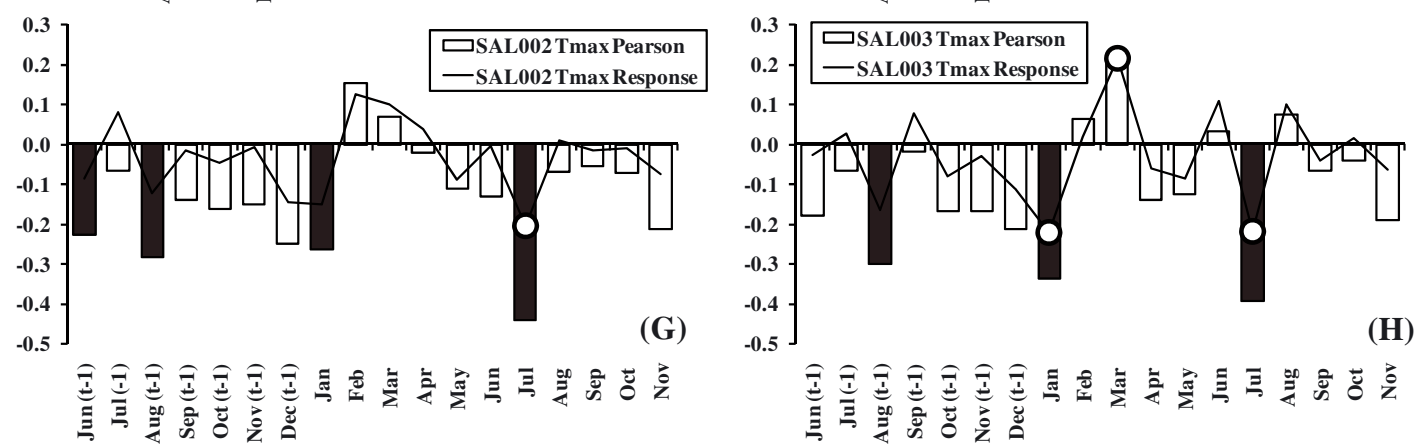

Figure 6. Bootstrapped correlation (bars) and response function (lines) coefficients between tree-ring indices and monthly climatic data from the previous year's June to the current year's December. Dark grey bars and white circles denote significant Pearson correlation and response function coefficients, respectively $(\alpha=0.05)$.

dendrochronology. Our results of good crossdating with pine tree-ring chronologies and the observed climate-growth correlations suggest that the temperate species rhythm (namely, cambial dormancy during winter) can be applied to $Q$. ilex in the studied location (Cherubini et al., 2003; Zhang and Romane, 1991). In this study we built the first chronology longer than $100 \mathrm{y}$ for the species $Q$. ilex. The relationship between growth and climate has changed over the life-span of the holm oaks in the 20th century, as has also been detected in other species under temperate climates (e.g. Carrer and Urbinati, 2006; Rozas, 2005) and in coniferous species in Spain (Andreu et al., 2007; Bogino and Bravo, 2008). Our results confirm that a similar increase in sensitivity to climate also affects the broadleaf evergreen species at the 

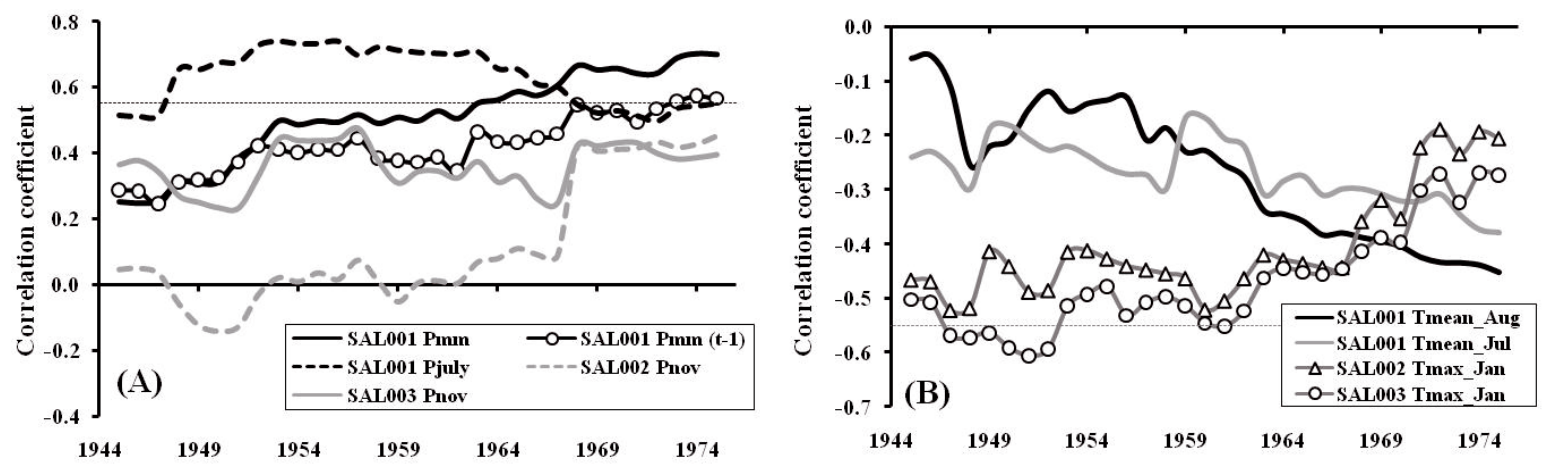

Figure 7. Thirty-year running average correlations between: (A) tree-ring index and cumulative annual precipitation (year, year+year -1 ) and tree-ring index and July and November precipitation; (B) tree-ring index and July and the previous year's August $(t-1)$ mean temperature. Horizontal dotted lines are statistical critical values $(\alpha=0.05)$ using Bonferroni correction $\left(\alpha^{\prime}=\alpha / 31=0.0016\right)$. Pmm $=$ annual precipitation; Tmean $=$ mean temperature Tmax $=$ month maximum temperature. The $x$ axis shows the first year of the 30-y period.

lower-mid-elevation site studied, which might also be extrapolated to other Mediterranean sites. The explanations for this sensitivity increase are difficult to assess (D'Arrigo et al., 2008) but could be related directly or indirectly to climate change, namely warming and increasing aridity in Iberia. Our chronology begins in 1864, immediately after the end of the Little Ice Age (Guiot et al., 2005; Luterbacher et al., 2006). The climatic records show that there has been an increase in temperature after the 1970s, leading to temperatures similar to those of the late 19th century and first half of the 20th century, which could explain the high sensitivity values observed in the late 19th century (Fig. 5B). However, this period of high sensitivity could also be partly explained by lower replication in the beginning of the chronology coinciding with growth at young ages.

Holm oak growth was mostly correlated with current and previous year precipitation, contrary to recent results in $P i$ nus brutia Ten. from the eastern Mediterranean, where longer periods (5 y) were more significant (Sarris et al., 2007). The characteristic response to summer climate of Mediterranean ecosystems was expressed by the studied population. Spring-summer and previous December's precipitation had a strong positive correlation with growth (Fig. 6A), similarly to Mediterranean deciduous Quercus species (Tessier et al., 1994). Nevertheless, there is no significant overall correlation between late-summer or early-autumn precipitation with growth, in accordance with results in other Mediterranean continental sites and contrary to those in milder locations (Cherubini et al., 2003) and in Mediterranean deciduous Quercus sp. (Tessier et al., 1994). The latter also show a significant positive response to late summer precipitation, therefore probably suggesting the existence of less water-stressed conditions (deciduous tree species tend to occupy more humid variants within the Mediterranean climate) and a less probable summer cambial stop. The high correlation of early summer precipitation with radial growth in holm oak is consistent with previous studies on the species under different Mediterranean climates, although all the studies available are from more north-eastern locations (Cartan-Son et al., 1992;
Cherubini et al., 2003; Corcuera et al., 2004; Nabais et al., 1998-1999; Zhang and Romane, 1991). Probably, rainy winters and springs coincide with rainy summers (Pearson $\rho=$ 0.58 between spring and July-August precipitation). The absence of greater correlations between growth and precipitation in spring than early summer (June-July) could also be explained by the fact that rain interannual variability is lower in spring (the rainy season), because trees indeed profit from spring precipitation. In addition, in this cool-wet location (for the species) holm oaks may be able to use July storm water despite high ETP rates (Rodá et al., 1999), when there is no competition from understory annual plants (dead in summer). Although this can vary with climate and site, shoot growth generally ceases in May-June (Castro-Díez and MontserratMartí, 1998; La Mantia et al., 2003). Thus, probably resources are first used primarily to build the photosynthetic tissues, and later diverted to xylem growth in order to increase water and nutrient uptake and transport, and tree structural resistance.

Radial growth was also most negatively correlated with summer temperatures which, together with the previously described relationships with precipitation, reflect the characteristic drought stress in Mediterranean ecosystems, also present in deciduous Quercus species (Tessier et al., 1994). Severe drought and excessive heat seem to cause a decrease in future growth during the next year because of poor bud formation and/or carbohydrate accumulation during the previous autumn. The absence of frosts would favour late autumn-winter photosynthesis and increase carbohydrate storage for future growth (Miyazawa and Kikuzawa, 2005). This might be the reason for the positive correlation of minimum temperatures in November and December of the previous year.

The reduction during the last few decades in the relationship of tree growth with July precipitation and the greater negative relationship with summer temperatures suggest that holm oaks are becoming more water-stressed in summer. This reaction is also similar to that of Pinus populations from mountain areas in eastern Spain (Andreu et al., 2007). In contrast, an increase in the relationship with precipitation triggered by the increase in summer water stress might have been expected, 
expressed by the increasing relationship with summer temperatures. However, this hypothesis being more unlikely, an alternative explanation might be the existence of an increase in competition with ageing of the stands, which would reduce the relationship with summer rain. We extend the discussion of the role of competition below. The absence of a longer climatic record prevents an analysis before the 1940s, but it might be thought that the climate-growth trend could be similar to that of sensitivity. The effect of increasing temperature upon plants, in the absence of an increase in precipitation, increases ETP rates and water stress, which together with increasing $\mathrm{CO}_{2}$ concentrations (Raupach et al., 2007) are likely to affect tree sensitivity and growth. Different authors report different responses to increasing $\mathrm{CO}_{2}$ concentrations, although in general relative radial growth increases in dry environments due to higher water-use efficiency (WUE) are expected (Hattenschwiler et al., 1997; Knapp et al., 2001; Soulé and Knapp, 2006; Tognetti et al., 2000). However, if ETP increases in Mediterranean ecosystems, water stress could dominate over the $\mathrm{CO}_{2}$-induced WUE increase (if any), resulting in important changes in latitudinal and altitudinal shift of species distribution (Benito Garzón et al., 2008). Species growing at low elevations in the Mediterranean, like $Q$. ilex in this study, are likely to be most susceptible to suffering the negative effects of climate change as a result of the combination of predicted reduced precipitation (Sumner et al., 2003) and increasing temperatures (IPCC, 2007).

In Western Iberia, evergreen oak woodlands of evergreen holm oak and/or Quercus suber (cork oak) dominate the landscape. Cork oaks in Portugal usually cease radial growth between December and February with diameter (xylem and bark) growth occurring all through the rest of the year (Costa et al., 2001; 2003), although this pattern might vary slightly between years and locations (Cartan-Son et al., 1992; Cherubini et al., 2003). It has also been observed that cork oaks in Portugal reach optimum growth (wood and cork) in June-July and growth is negatively correlated with August temperature, similarly to the relationships we observed. In southern Spain, holm and cork oaks generally enter dormancy twice (in winter and summer; J. Vázquez, personal communication). The occurrence of summer or winter-summer double cambial dormancy has been shown to differ in other species and different distribution areas in the Mediterranean, and it is also likely to vary in years with different climatic conditions (Cherubini et al., 2003; Liphschitz and Lev-Yadum, 1986). Except in soils with high water accumulation, water is the most limiting factor for growth and its influence decreases with altitude in the Mediterranean region, with temperature showing the opposite trend. Cherubini et al. (2003) suggest that not all holm oak treering chronologies from different locations necessarily share a climatic signal and therefore they might express different responses to climate.

\subsection{Tree density influence on tree response to climate}

The tree response to climate is partly modified by competition, which can be controlled by management (Cescatti and
Piutti, 1998; Misson et al., 2003). Our holm oak population exhibited a certain amount of plasticity to climatic changes, and plasticity increased when comparing the different density scenarios. Correlation with maximum temperature in early and late winter, and with November precipitation, were stronger in high density than in low density stands, suggesting a longer growing season. In high density stands, rings were narrower, and ring boundaries less clear (Tab. I; Gea-Izquierdo et al., 2009). The effect of competition and greater rainfall interception in high density stands was probably reflected in their lower correlation with early summer precipitation. However, the smaller negative correlations with summer temperatures in high density stands also suggest that, in spite of higher competition and probably consequent worse water status in individual trees (Moreno and Cubera, 2008), they might be likely to smooth to some extent the response to increasing temperature (Martín-Benito et al., 2008), at least in the cool-wet site analysed. In addition, the low density stands have been changing the relationship with the late autumn-early winter climate in the last few decades (Fig. 7), most probably reflecting an expansion of the growing season or higher photosynthetic rates during those months. Photosynthesis start and stop are gradual processes (Berninger, 1997); thus some of the relationships described with late autumn or winter climate variables might be responding to photosynthetic activity. Our studied location can be considered as a mesic site for the studied species, and the climate-growth relationships are likely to differ from those in drier sites, as suggested by Moreno and Cubera (2008) analysing ecophysiological variables.

The reduction of stand density through thinning has been suggested to increase the resistance of individual trees to drought stress and the extent of this differential response changes within the same species along climatic gradients (Misson et al., 2003; Moreno and Cubera, 2008). However, we consider that this conclusion should not be extrapolated to generalise that open stands are always desirable. In our site, density affects the climate-growth relationship, but it is difficult to assess whether higher densities could be more resistant to increased drought in the long term at the stand level. We consider that a more careful overall analysis of the ecosystem should be done before providing management guidelines which suggest opening the closed stands (as humans have done in the past) in this degraded, threatened ecosystem. Natural ecosystems in dry environments, such as natural savannas, tend to reduce density in response to decreasing precipitation, which has also been suggested as a hypothesis for the ecosystem studied (Joffre et al., 1999). However, this ecosystem was most likely primarily a closed forest, and opening of stands by humans in the past pursued the creation of silvopastoral use rather than ecosystem conservation. Today other goals such as multipurpose management exist as a consequence of socioeconomic changes. Denser stands than those currently dominating the landscape might result in improvements for the microclimate (i.e. for regeneration, Pulido and Díaz, 2005) and soil protection, which might prevail over individual tree status and competition when providing management guidelines, even if higher risk of individual dieback might occur (Peñuelas et al., 2001; Rodá et al., 1999). 
The consequences of climatic change for species growth and distribution need to be closely monitored, particularly in water-limited regions and degraded soils like those found in many locations along the Mediterranean. If warming continues and certain thresholds are exceeded, trees might not be able to adapt as they seem to be currently doing, as shown by their increase in sensitivity and possible growing season length adaptations. Therefore, abrupt changes in species distribution following an increase in temperature and ETP in the Mediterranean are likely to be expected (Benito-Garzón et al., 2007). Management should adapt to this climatic variability, through stand competition management and/or favouring the establishment of more adapted species to the expected climatic scenarios. This could be done by selecting between the rich pool of native Quercus sp. found in the region or by favouring a probably more natural combination of mixed native conifers and broadleaf trees. Much research is still required to properly address these important issues.

\section{CONCLUSIONS}

In this study we have built the first $Q$. ilex chronology longer than a century. It is additionally important as one of the few mid-/low elevation and first evergreen hardwood chronologies from West Iberia. Quercus ilex sp. ballota sensitivity and radial growth response to climate varies with changing climate, as previous studies have shown in other species. Evergreen oak forests in western Iberia are positively affected by late spring and early summer precipitation and negatively affected by high temperatures in summer, similarly to deciduous Mediterranean oak forests. Summer climatic conditions have become a greater stress on growth, probably as a consequence of recent warming, whereas the growing season could be expanding. Management might play, to a certain extent, a role in mitigating climate change through, e.g., stand density. Our higher density stands exhibited a smoother response to climate, and to a certain extent seemed to be able to buffer their response to climate warming. Whether our results are comparable with those from warmer and/or drier locations also occupied by holm oak remains to be analysed. The differences observed for different densities should be carefully regarded and complemented with other studies to obtain directions for management of these woodlands.

Acknowledgements: We gratefully acknowledge all authors that provided data to the ITRDB. E. Garriga thoroughly processed the samples. E. Gill revised the English and made helpful remarks. R. Calama, L. Cruz and PyG facilitated the contacts to obtain holm oak samples from Salamanca. Climatic data was provided by the Spanish National Meteorological Institute. Two anonymous reviewers helped to increase the quality of the final version.

\section{REFERENCES}

Andreu L., Gutiérrez E., Macías M., Ribas M., Bosch O., and Camarero J.J., 2007. Climate increases regional tree-growth variability in Iberian pine forests. Global Change Biol. 13: 804-815.
Barbero M., Loisel R., and Quézel P., 1992. Biogeography, ecology and history of Mediterranean Quercus ilex ecosystems. Vegetatio 99100: 19-34.

Benito-Garzón M., Sánchez de Dios R., and Sainz Ollero H., 2008. Effects of climate change on the distribution of Iberian tree species. Appl. Veg. Sci. 11: 169-178.

Berninger F., 1997. Effects of drought and phenology on GPP in Pinus sylvestris: A simulation study along a geographical gradient. Funct. Ecol. 11: 33-42.

Biondi F. and Waikul K., 2004. DENDROCLIM2002: A C++ program for statistical calibration of climate signals in tree-ring chronologies. Comput. Geosci. 30: 303-311.

Briffa K.R., Schweingruber F.H., Jones P.D., Osborn T.J., Harris I.C., Shiyatov S.G., Vaganov E.A., and Grudd H., 1998. Trees tell of past climates: but are they speaking less clearly today? Philos. Trans. R. Soc. B Biol. Sci. 353: 65-73.

Briffa K.R., Osborn T.J., Schweingruber F.H., Jones P.D., Shiyatov S.G., and Vaganov E.A., 2002. Tree-ring width and density data around the Northern Hemisphere: Part 1, Local and regional climate signals. Holocene 12: 737-757.

Bogino S. and Bravo F., 2008. Growth response of Pinus pinaster Ait. to climatic variables in central Spanish forests Ann. For. Sci. 65: 506.

Campelo F., Gutierrez E., Ribas M., Nabais C., and Freitas H., 2007. Relationships between climate and double rings in Quercus ilex from northeast Spain. Can. J. For. Res. 37: 1915-1923.

Cartan-Son M., Floret C., Galan M.J., Grandjanny M., Lefloch E., Maistre M., Perret P., and Romane F., 1992. Factors affecting radial growth of Quercus ilex L. in a coppice stand in southern France. Vegetatio 100: 61-68.

Carrer M. and Urbinati C., 2006. Long-term change in the sensitivity of tree-ring growth to climate forcing in Larix decidua. New Phytol. 170: 861-871.

Castro-Díez P. and Montserrat-Martí G., 1998. Phenological pattern of fifteen Mediterranean phanaerophytes from Quercus ilex communities of NE-Spain. Plant Ecol. 139: 103-112.

Cescatti A. and Piutti E., 1998. Silvicultural alternatives, competition regime and sensitivity to climate in a European beech forest. For. Ecol. Manage. 102: 213-223.

Cherubini P., Gartner B.L., Tognetti R., Bräker O.U., Schoch W., and Innes J.L., 2003. Identification, measurement and interpretation of tree rings in woody species from mediterranean climates. Biol. Rev. 78: $119-148$.

Cook E.R. and Kairiukstis L.A., 1990. Methods of Dendrochronology. Applications in the Environmental Sciences, Kluwer, The Netherlands.

Cook E.R., 1985. A time series analysis approach to tree ring standardization, $\mathrm{PhD}$ dissertation, University of Arizona, Tucson, Arizona.

Corcuera L., Camarero J.J., and Gil-Pelegrín E., 2004. Effects of severe drought on Quercus ilex radial growth and xylem anatomy. Trees 18: 83-92.

Costa A., Pereira H., and Oliveira A., 2001. A dendroclimatological approach to diameter growth in adult cork-oak trees under production. Trees 15: 438-443.

Costa A., Pereira H., and Oliveira A., 2003. Variability of radial growth in cork oak adult trees under cork production. For. Ecol. Manage. 175: 239-246.

D'Arrigo R., Wilson R., Liepert B., and Cherubini P., 2008. On the "Divergence problem" in Northern forests: a review of the tree-ring evidence and possible causes. Global Planet. Change. 60: 289-305.

Fritts H.C., 1976. Tree rings and climate, Blackburn Press, 567 p.

García del Barrio J.M., Bolaños F., Ortega M., and Elena-Rosselló R., 2004. Dynamics of land use and land cover change in dehesa landsapes of the "REDPARES" network between 1956 and 1998. In: Schnabel S. and Ferreira A. (Eds.), Sustainability of agrosilvopastoral systems, Advances in Geoecology 37, Catena Verlag, 99. 47-54. 
Gea-Izquierdo G., Cañellas I., and Montero G., 2008. Site index in agroforestry systems: age-dependent and age-independent dynamic diameter growth models for Quercus ilex in Iberian open oak woodlands. Can. J. For. Res. 38: 101-113.

Gea-Izquierdo G. and Cañellas I., 2009 Analysis of holm oak intraspecific competition using Gamma regression. For. Sci. 55: 310-322.

Génova M., Fernández Cancio A., and Creus J., 1993. Diez series medias de anillos de crecimiento en los sistemas Carpetano e Ibérico. Investig. Agrar. Sist. Recur. For. 2: 151-172.

Grissino-Mayer H.D., 2001. Evaluating crossdating accuracy: a manual and tutorial for the computer program COFECHA. Tree-Ring Bull. 57: 205-221.

Guiot J., Nicault A., Rathgeber C., Edouard J.L., Guibal E., Pichard G., and Till C., 2005. Last-millennium summer-temperature variations in western Europe based on proxy data. Holocene 15: 489-500.

Hattenschwiler S., Miglietta F., Raschi A., and Korner C., 1997. Thirty years of in situ tree growth under elevated $\mathrm{CO}_{2}$ : a model for future forest responses? Global Change Biol. 3: 463-471.

Huang J.G., Tardif J., Denneler B., Bergeron Y., and Berninger F., 2008. Tree-ring evidence extends the historic northern range limit of severe defoliation by insects in the aspen stands of western Quebec, Canada. Can. J. For. Res. 38: 2535-2544.

IPCC, 2007. Climate Change 2007: Synthesis Report. Contribution of Working Groups I, II and III to the Fourth Assessment Report of the Intergovernmental Panel on Climate Change, Core Writing Team, Pachauri R.K. and Reisinger A. (Eds.). IPCC, Geneva, Switzerland, $104 \mathrm{p}$.

Joffre R., Rambal S., and Ratte J.P., 1999. The dehesa system of Southern Spain and Portugal as a natural ecosystem mimic. Agrof. Syst. 45: 57-79.

Kaennel M. and Schweingruber F.H. (Compilers) 1995. Multilingual glossary of dendrochronology. Terms and definitions in English, German, French, Spanish, Italian, Portuguese and Russian, Berne, Stuttgart, Vienna, Haupt, Bern, p. 467.

Kimmins J.P., 1997. Forest ecology, Prentice Hall Inc, NJ, p. 596.

Knapp P.A., Soulé P.T., and Grissino-Mayer H.D., 2001. Detecting potential regional effects of increased atmospheric $\mathrm{CO}_{2}$ on growth rates of western juniper. Global Change Biol. 7: 903-917.

La Mantia T., Cullotta S., and Garfi G., 2003. Phenology and growth of Quercus ilex L. in different environmental conditions in Sicily (Italy). Ecol. Medit. 29: 15-25.

Liphschitz N. and Lev-Yadum S., 1986. Cambial activity of evergreen and seasonal dimorphics around the Mediterranean. IAWA J. 7: 145-153.

Luterbacher J., Xoplaki E., Casty C., et al., 2006. Mediterranean climate variability over the last centuries: A review. In Lionello P., Malanotte-Rizzoli P., and Boscolo R. (Eds.), Mediterranean climate variability, Developments in Earth and Environmental Sciences, Elsevier, Amsterdam, p. 27-148.

Macías M., Andreu L., Bosch O., Camarero J.J., and Gutiérrez E., 2006. Increasing aridity is enhancing silver fir (Abies alba mill.) water stress in its south-western distribution limit. Climatic Change 79: 289-313.

Martín-Benito D., Cherubini P., del Río M., and Cañellas I., 2008. Growth response to climate and drought in Pinus nigra Arn. trees of different crown classes. Trees 22: 363-373.

Misson L., Nicault A., and Guiot J., 2003. Effects of different thinning intensities on drought response in Norway spruce (Picea abies (L.) Karst.). For. Ecol. Manage. 183: 47-60.
Miyazawa Y. and Kikuzawa K., 2005. Winter photosynthesis by saplings of evergreen broad-leaved trees in a deciduous temperate forest. New Phytol. 165: 857-866.

Moreno G. and Cubera E., 2008. Impact of stand density on water status and leaf gas exchange in Quercus ilex. For. Ecol. Manage. 254: 74-84.

Nabais C., Freitas H., and Hagemeyer J., 1998-1999. Tree rings to climate relationships of Quercus ilex L. in NE-Portugal. Dendrochronologia 16-17: 37-44.

Olea L. and San Miguel A., 2006. The Spanish dehesa: a traditional Mediterranean silvopastoral system linking production and nature conservation. 21st General Meeting of the European Grassland Federation, April 3-6, 2006. Badajoz (Spain).

Peñuelas J., Lloret F., and Montoya R., 2001. Severe drought effects on Mediterranean woody flora in Spain. For. Sci. 47: 214-218.

Pulido F.J. and Díaz M., 2005. Regeneration of a Mediterranean oak: A whole-cycle approach. Ecoscience 12: 92-102.

Raupach M.R., Marland G., Ciais P., Le Quere C., Canadell J.G., Klepper G., and Field C.B., 2007. Global and regional drivers of accelerating $\mathrm{CO}_{2}$ emissions. Proc. Natl Acad Sci USA 104: 10288-10293.

Richter K., Eckstein D., and Holmes R.L., 1991. The dendrochronological signal of pine trees (Pinus spp.) in Spain. Tree-Ring Bull. 51: $2-13$.

Rinntech, 2003. TSAP-WIN. Time series analysis and presentation for dendrochronology and related applications, Version 0.53.

Rodá R., Retana J., Gracia C.A., and Bellot J., 1999. Ecology of Mediterranean evergreen oak forests, Springer-Verlag, Berlin, 373 p.

Rodrigo F.S. and Trigo R.M., 2007. Trends in daily rainfall in the Iberian Peninsula from 1951 to 2002. Int. J. Climatol. 27: 513-529.

Rozas V., 2005. Dendrochronology of pedunculate oak (Quercus robur L.) in an old-growth pollarded woodland in northern Spain: tree-ring growth responses to climate. Ann. For. Sci. 62: 209-218.

Ruiz de la Torre J., 1979. Árboles y arbustos de la España peninsular. Fundación del Conde Valle de Salazar, Madrid, Spain.

Sarris D., Christodoulakis D., and Körner C., 2007. Recent decline in precipitation and tree growth in the eastern Mediterranean. Global Change Biol. 13: 1187-1200.

Soulé P.T. and Knapp P.A., 2006. Radial growth rate increases in naturally occurring ponderosa pine trees: a late-20th century $\mathrm{CO} 2$ fertilization effect? New Phytol. 171: 379-390.

Sumner G.N., Romero R., Homar V., Ramis C., Alonso S., and Zorita E., 2003. An estimate of the effects of climate change on the rainfall of Mediterranean Spain by the late twenty first century. Clim. Dynam. 20: 789-805.

Swetnam T.W., Thompson M.A., and Kennedy-Sutherland E., 1985. Using dendrochronology to measure radial growth of defoliated trees, US Forest Service Handbook No. 639.

Tessier L., Nola P., and Serre-Bachet F., 1994. Deciduous Quercus in the Mediterranean Region: tree-ting/climate relationships. New Phytol. 126: $355-367$

Tognetti R., Cherubini P., and Innes J.L., 2000. Comparative stem-growth rates of Mediterranean trees under background and naturally enhanced ambient $\mathrm{CO}_{2}$ concentrations. New Phytol. 146: 59-74.

Zhang S.H. and Romane F., 1991. Variations de la croissance radiale de Quercus ilex L. en fonction du climat. Ann. Sci. For. 48: 225-234. 